\title{
Correlation between Proteinuria and Glomerular Filtration Rate in Type 2 Diabetes Mellitus
}

\author{
Dani Rosdiana, ${ }^{1}$ Mukhyarjon, ${ }^{1}$ Hendra Asputra, ${ }^{1}$ Nisa Faradisa, ${ }^{2}$ Olivia Makmur, ${ }^{2}$ Prayogo, ${ }^{2}$ \\ Hetty Hirfawaty ${ }^{2}$ \\ ${ }^{1}$ Department of Internal Medicine, Faculty of Medicine University of Riau/Arifin Achmad General Hospital, \\ Pekanbaru, Riau, Indonesia, ${ }^{2}$ Faculty of Medicine University of Riau, Pekanbaru, Indonesia
}

\begin{abstract}
Indonesia faces a double burden of communicable and non-communicable diseases, including metabolic and degenerative problems. Delay in the detection of diabetic nephropathy (DN) as one of the chronic microvascular complications is often seen, leading to the need for hemodialysis due to the end-stage renal disease (ESRD). An assessment of diabetes mellitus (DM) control target achievement, based on the guideline from the Indonesian Society of Endocrinology (Perkumpulan Endokrinologi Indonesia, PERKENI), and nephropathy early detection was performed in 54 Type-2 DM patients from 5 private hospitals in Pekanbaru Riau, Indonesia, from November 2018 to September 2019. Results showed poor achievement of DM control with $61.1 \%$ had abnormal body mass index (BMI), 57.5\% had HbA1c > 7\%, and 77.7\% had LDL serum $>100 \mathrm{mg} / \mathrm{dL}$. Nevertheless, most patients achieved good blood pressure control (74\%). A high percentage of nephropathy-proteinuria was seen (40.7\%) with $40.9 \%$ of them revealed renal insufficiency classified as chronic kidney disease (CKD) stage 3 and 4. There was a significant correlation between proteinuria and declined GFR $(\mathrm{p}=0.016)$, onset of DM $(\mathrm{p}=0.02)$, and diastolic blood pressure $(p=0.03)$. No correlation was found between HbA1c and declined GFR, which may be due to the cross-sectional nature of the study. It will be interesting to perform a prospective study on proteinuria modification as a predictor of nephropathy early detection in DM patients since kidney biopsy and urine albumin creatinine ratio assessment are not available in primary health care services in remote areas.
\end{abstract}

Key words: Diabetic control, diabetic nephropathy, GFR, HbA1c, proteinuria, type-2 DM

\section{Korelasi antara Proteinuria dan Laju Filtrasi Glomerulus pada Diabetes Melitus Tipe 2}

\begin{abstract}
Abstrak
Indonesia menghadapi beban ganda penyakit menular dan tidak menular, termasuk masalah metabolisme dan degeneratif. Keterlambatan dalam deteksi nefropati diabetik sebagai salah satu komplikasi mikrovaskular kronis sering terlihat, mengarah pada kebutuhan untuk hemodialisis karena penyakit ginjal stadium akhir (ESRD). Sebanyak 54 pasien diabetes melitus (DM) tipe-2 tanpa keluhan edema, sesak, dan lemas dari 5 rumah sakit swasta di Pekanbaru, Riau, Indonesia, dari November 2018 hingga September 2019, dilakukan penilaian kontrol DM sesuai panduan Perkumpulan Endokrinologi Indonesia (PERKENI). Didapatkan hasil bahwa pencapaian kontrol DM masih buruk dengan 61,1\% memiliki indeks massa tubuh abnormal 57,5\% memiliki HbA1c > 7\%, dan 77,7\% memiliki serum LDL $>100 \mathrm{mg} / \mathrm{dL}$. Namun demikian, sebagian besar pasien mencapai kontrol tekanan darah yang baik (74\%). Pasien terdeteksi proteinuria $>25 \mathrm{mg} / \mathrm{dL}$ mencapai 40,7\% dengan 40,9\% diantaranya mengalami gangguan filtrasi ginjal yang didefinisikan sebagai GFR<60 diklasifikasikan penyakit ginjal kronis tahap 3 dan 4 . Walaupun secara statistik tidak ditemukan hubungan bermakna antara kontrol glikemik dan insufisiensi renal, namun ditemukan hubungan bermakna antara nefropati dan penurunan laju filtrasi glomerulus (GFR) ( $p=0.016)$, awitan DM ( $p=0,02)$, dan tekanan darah diastolik $(\mathrm{p}=0,03)$. Tidak ada hubungan bermakna antara HbA1c dan penurunan GFR yang mungkin disebabkan observasi sesaat. Akan menarik untuk melakukan penelitian prospektif modifikasi proteinuria sebagai prediktor deteksi dini nefropati pada pasien DM karena biopsi ginjal dan penilaian rasio albumin kreatinin urin tidak tersedia di layanan perawatan kesehatan primer di daerah terpencil.
\end{abstract}

Kata kunci: Diabetes melitus tipe-2, kontrol DM, laju filtrasi glomerulus (GFR), nefropati diabetik, proteinuria

Corresponding Author: Dani Rosdiana, Department of Internal Medicine, Faculty of Medicine University of Riau/Arifin Achmad General Hospital, Jalan Diponegoro No. 1, Pekanbaru, Riau, Indonesia, Email: dr.danirosdiana123@gmail.com 


\section{Introduction}

As with many other countries, Indonesia currently faces high economic, social, and health burdens that come from both metabolic degenerative and infectious diseases. Diabetes Mellitus (DM), as one of the metabolic degenerative diseases, requires abundant resources to manage the macro- and microvascular complications caused by the disease. A national survey in Indonesia reported that the prevalence of DM in the population above 15 years old has reached 5.7\%, especially in urban areas. ${ }^{1}$ People with diabetes who cannot maintain adequate glycemic control (reflected by, among others, failure to reach the recommended target level of HbA1c <7\%) have a predisposition to develop neuropathy, retinopathy, nephropathy, cardiovascular disease, cerebrovascular disease, and even premature death. ${ }^{2}$ These are originated from the pathologic hallmark of DM that involves vascular complications, both microvascular and macrovascular complications. ${ }^{3}$

Diabetic kidney disease (DKD) is a common complication of DM and the leading cause of chronic kidney disease (CKD) in the developed world. Approximately $40 \%$ of persons with DM develop DKD manifested as albuminuria, impaired glomerular filtration rate (GFR), or both, which will then become the leading risk factor for renal impairment. ${ }^{5}$ End-stage kidney disease (ESKD) due to diabetic nephropathy (DN) is one of the common indications for renal replacement therapy worldwide. ${ }^{6}$ Unfortunately, most diabetic patients are not aware of the renal insufficiency until they experience dyspnea, lethargy, anemia, and edema as uremic syndrome manifestation. At present, the gold standard for DN diagnosis is the pathological examination of renal biopsies. However, renal biopsy is an invasive procedure with a range of limitations. Notably, renal biopsy is difficult to perform in non-specialist hospitals, particularly in rural and remote areas. ${ }^{7}$ Some rural areas in Indonesia, including Riau rural areas, even do not have access to microalbuminuria or ACR testing. This study aimed to assess the possibility to employ proteinuria measurement, which can be easily performed in the point of care, to screen DN, which in turn will inhibit the progression of CKD. As the leading cause of CKD, DKD is influenced by various risk factors that are usually reflected in several laboratory variables, including $\mathrm{HbA} 1 \mathrm{c}$. However, data on the HbA1c level are limited because it is not included in routine testing due to limited availability and high cost. This leads to the lack of data on DM control achievement and early diabetic nephropathy for these patients in rural hospitals, including in Riau, Indonesia.

\section{Methods}

This was a cross-sectional study on 54 type 2 DM patients recruited from private hospitals in Pekanbaru, Riau, between November 2018 and September 2019. The protocols and ethical clearance were approved by the Ethical Committee of the Faculty of Medicine, University of Riau (Ethical Clearance No: B/175/ UN.19.5.1.1.8/UEPKK/2019). Sampling was performed using the simple randomized sampling approach in 5 hospitals in Pekanbaru as the population. The inclusion criteria for this study were diagnosed with Type 2 DM by an internist; no symptoms such as dyspnea, edema, paleness, and cor; lungs in normal limits; routine visits to the doctor for the last six months; and agreed to participate in this study by signing the informed consent and stated the willingness to undergo several anamnesis, physical examinations, and laboratory sampling. Patients who had anemia and/or hypertriglyceridemia are excluded from this study.

Data collected in this study were patient profiles and clinical characteristics of DM control indicators such as $\mathrm{HbA1c}$, lipid profile, and uric acid. The glycemic control goal used referred to the PERKENI guideline, namely Blood pressure $<140 / 80 \mathrm{mmHg}$, body mass index (BMI) $<25$ $\mathrm{kg} / \mathrm{m}^{2}$ as the anthropometric index, HbA1c $<7 \%$, low density lipid (LDL) $<100 \mathrm{mg} / \mathrm{dL}$, and Triglyceride serum $<150 \mathrm{mg} / \mathrm{dL}$. Proteinuria was also measured in this study with protein excretion of over $30 \mathrm{mg} / \mathrm{g}$ considered to indicate proteinuria. The eGFR was calculated using the Cockcroft gault formula.

Analysis was performed using the chi-square test for categorical data and the non-paired t-test for numerical data.

\section{Results}

From 74 Type 2 DM patients who meet the inclusion criteria in the five private hospitals, only 54 patients completed the examinations, which consisted of 24 males and 30 females. Table 1 showed that the older age group had a higher tendency to suffer from renal insufficiency, whereas the onset of DM ranged from 2-11 years before the study. The information about the 
Table 1 Distribution Frequency of Demographic

\begin{tabular}{|c|c|c|c|c|}
\hline \multirow[b]{2}{*}{ Characteristics } & \multirow{2}{*}{$\begin{array}{l}\text { Total }(n=54) \\
\quad n(\%)\end{array}$} & \multicolumn{2}{|c|}{ Renal Function } & \multirow[b]{2}{*}{ p-value } \\
\hline & & Normal & $\begin{array}{c}\text { Renal } \\
\text { Insufficiency }\end{array}$ & \\
\hline Age & $55.52 \pm 11.5$ & $53.02 \pm 11.3$ & $63.38 \pm 8.6$ & 0.43 \\
\hline \multicolumn{5}{|l|}{ Sex } \\
\hline Male & $24(44.4 \%)$ & 18 & 6 & \multirow{2}{*}{0.88} \\
\hline Female & $30(55.6 \%)$ & 23 & 7 & \\
\hline Onset of DM & $6.15 \pm 4.3$ & $5.37 \pm 3.4$ & $8.62 \pm 6$ & 0.02 \\
\hline \multicolumn{5}{|c|}{$\begin{array}{l}\text { GFR: glomerular filtration rate, calculated by the Cockcroft Gault formula. Normal GFR was classified as GFR }<60 \mathrm{n} \\
\mathrm{min} / 1.73 \mathrm{~m}^{2} \text {, whereas Renal Insufficiency was defined as GFR } \geq 60 \mathrm{~mL} / \mathrm{min} / 1.73 \mathrm{~m}^{2}\end{array}$} \\
\hline \multicolumn{2}{|c|}{ Subjects Characteristic } & Good Achievement & \multicolumn{2}{|c|}{ Poor Achievement } \\
\hline \multicolumn{2}{|l|}{$\begin{array}{l}\text { Waistcircumference } \\
\text { male }^{*} \text {, female* }\end{array}$} & $15 / 54(27.7 \%)$ & \multicolumn{2}{|c|}{ Over 39/54 (72.2\%) } \\
\hline \multicolumn{2}{|l|}{ BMI } & $21 / 54(38.8 \%)$ & \multicolumn{2}{|c|}{$33 / 54(61.1 \%)$} \\
\hline \multicolumn{2}{|l|}{ Diastolic blood pressure } & $40 / 54(74.1 \%)$ & \multicolumn{2}{|c|}{$14 / 54(25.9 \%)$} \\
\hline \multicolumn{2}{|l|}{$\mathrm{HbA1c}$} & $23 / 54(42.6 \%)$ & \multicolumn{2}{|c|}{$531 / 54(57.4 \%)$} \\
\hline \multicolumn{2}{|l|}{ LDL } & $12 / 54(22.3 \%)$ & \multicolumn{2}{|c|}{$42 / 54(77.7 \%)$} \\
\hline \multicolumn{2}{|l|}{ Triglyceride } & $38 / 54(70.3 \%)$ & \multicolumn{2}{|c|}{$16 / 54(29.7 \%)$} \\
\hline
\end{tabular}

*waist circumference: IDF criteria: male $<90 \mathrm{~cm}$, female $<80 \mathrm{~cm}$

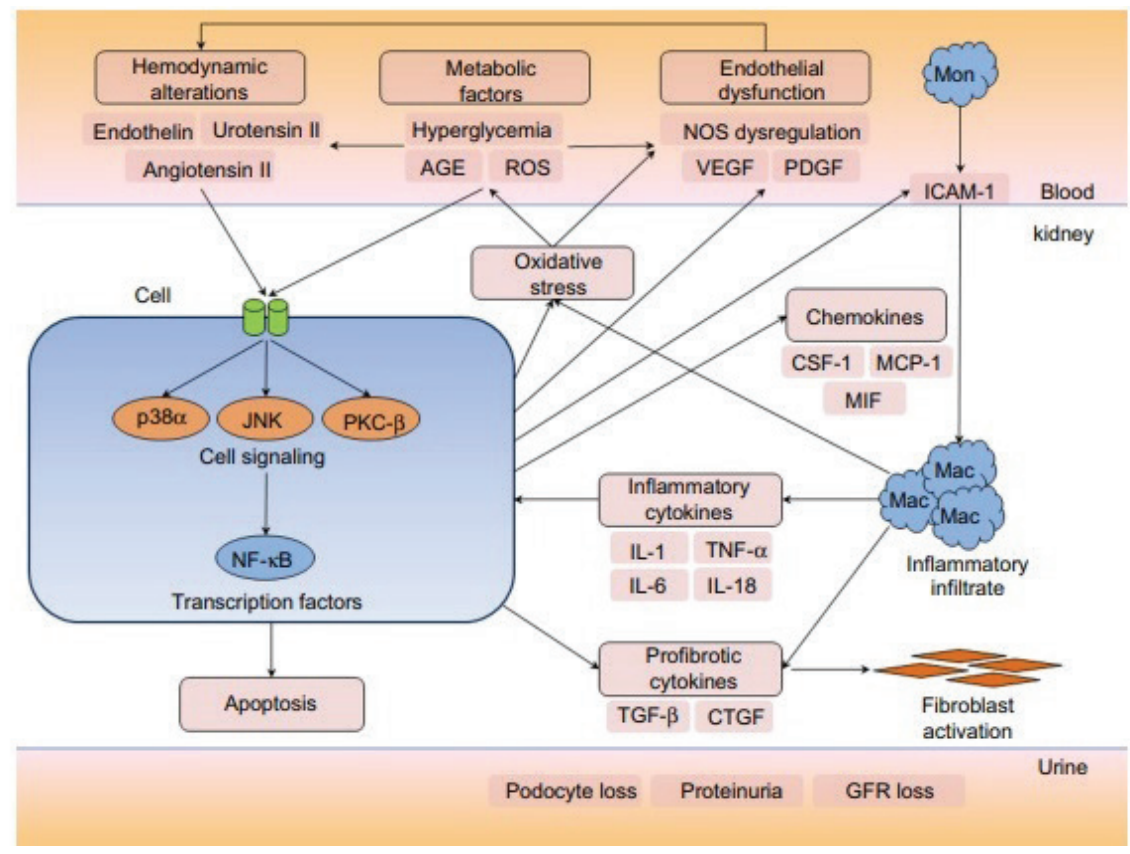

Figure Pathophysiology of DM Complication

Source: Lim AKH. Diabetic nephropathy-Complications and treatment. Int J Nephrol Renovasc Dis. 2014;7:361-81. 
D Rosdiana, et al: Correlation between Proteinuria and Glomerular Filtration Rate in Type 2 Diabetes Mellitus

Table 3 Clinical and Biochemical Characteristics of DM Control Target

\begin{tabular}{lcccc}
\hline \multirow{2}{*}{ DM Control Target } & \multirow{2}{*}{$\begin{array}{c}\text { Total } \\
(\mathbf{n = 5 4 )}\end{array}$} & \multicolumn{2}{c}{ Renal Function } & p-value \\
\cline { 2 - 4 } & $97.81 \pm 12.3$ & $98.17 \pm 12.8$ & $96.69 \pm 11$ & 0.53 \\
Waist Circumference & $27.51 \pm 4.5$ & $27.7 \pm 4.6$ & $26.59 \pm 4.4$ & 0.33 \\
BMI & $147.72 \pm 21.2$ & $144.83 \pm 18.7$ & $156.85 \pm 26.3$ & 0.13 \\
Systolic BP & $83.31 \pm 12$ & $83.27 \pm 11.1$ & $83.46 \pm 15$ & 0.03 \\
Diastolic BP & $7.5 \pm 1.7$ & $7.78 \pm 1.7$ & $6.63 \pm 1.35$ & 0.15 \\
HbA1C & $50.63 \pm 10.5$ & $50.68 \pm 10.1$ & $50.46 \pm 12.1$ & 0.58 \\
HDL & $124.57 \pm 32.3$ & $126.61 \pm 29.7$ & $118.15 \pm 40.1$ & 0.14 \\
LDL & $137.76 \pm 60.5$ & $144.05 \pm 62.4$ & $117.92 \pm 51.4$ & 0.45 \\
Triglyceride & $5.8 \pm 1.63$ & $5.5 \pm 1.4$ & $7.08 \pm 1.6$ & 0.77 \\
Uric Acid & Insufficiency & \\
\hline
\end{tabular}

Waist circumference in cm, BMI measurement in $\mathrm{kg} / \mathrm{m}^{2}$, blood pressure in $\mathrm{mmHg}, \mathrm{HbA1c}$ in \%, LDL in mg/dL, TG in mg/ $\mathrm{dL}$, HDL in $\mathrm{mg} / \mathrm{dL}$, Uric Acid in $\mathrm{mg} / \mathrm{dL}$

onset of DM was based on patients' statements during the anamnesis and has to be treated with care. From the clinical experience, there are patients who visit the doctor, complaining about non-classical DM symptoms and signs that have lasted for years. No significant difference was observed in the distribution of demographic data in terms of age and sex.

Table 2 showed that the DM control achieved was not satisfactory. All parameters, based on the PERKENI guideline, were found to be poor except blood pressure and triglyceride level parameters. Interestingly, the diastolic blood pressure parameter was attained in $74 \%$ and the Triglyceride level parameter achievement was $70.3 \%$. Further data on the correlations between these parameters to GFR decline are listed in Table 3.

Indicators for good achievement based on the PERKENI guideline: BMI as calculated using body weight $(\mathrm{kg}) /$ height $\left(\mathrm{m}^{2}\right)$ of $<25 \mathrm{~kg} / \mathrm{m}^{2}$, blood pressure (BP) of $<140 / 90 \mathrm{mmHg}$, HbA1c of $<7 \%$, LDL $<100 \mathrm{mg} / \mathrm{dL}$, TG of $<150 \mathrm{mg} / \mathrm{dL}$.

Statistic analysis showed a significant correlation between diastolic blood pressure and GFR decline. However, no significant correlations were seen between waist circumference, BMI, HbA1c, LDL, triglyceride level, and GFR decline. PERKENI recommended assessing the clinical and biochemical targets routinely in order to detect advanced complications and delayed disease progressivity in T2 DM. However, this is rarely done by hospitals and primary health care facilities. It is not surprising then that patients' long-term data are seldom available (Table 3).

Diabetic Nephropathy diagnosis was made by examining proteinuria, creatinine serum, and ureum serum. Cockcroft gault formula was used to calculate and analyze this correlation. All participants did not have dyspnea, edema, oliguria, pale, and lethargy complaints. Table 4 showed that $40.7 \%$ of patients had proteinuria

Table 4 Correlation between Proteinuria and GFR Decline

\begin{tabular}{lcccc}
\hline \multirow{2}{*}{ Characteristics } & Total (n=54) & \multicolumn{2}{c}{ Renal Function } & p-value \\
\cline { 3 - 3 } & $\mathbf{n ~ ( \% )}$ & Normal & Insufficiency & \\
\hline Protein urine & & & & \\
0 & $32(59.3 \%)$ & $28(68.3 \%)$ & $4(30.8 \%)$ & 0.016 \\
+1 & $6(11.1 \%)$ & $5(12.2 \%)$ & $1(7.7 \%)$ & \\
+2 & $5(9.3 \%)$ & $1(2.4 \%)$ & $4(30.8 \%)$ & $2(15.4 \%)$ \\
+3 & $5(9.3 \%)$ & $3(7.3 \%)$ & $2(15.4 \%)$ & 0.001 \\
\hline 4
\end{tabular}


in various degrees, ranging from positive 1 to 4 with $11.1 \%$ had 4 th-degree proteinuria, but patients were not aware of future renal failure threats. Still, this simple examination was also not performed routinely. Of all patients in the renal insufficiency group, $70 \%$ had proteinuria. A significant correlation between proteinuria and GFR decline was observed.

\section{Discussion}

All forms of diabetes are characterized by hyperglycemia, including relative or absolute lack of insulin action, pathway-selective insulin resistance, and diabetes-specific pathological developments in the retina, renal glomerulus, and peripheral nerves. Diabetic microvascular complications are caused by prolonged exposure to high glucose levels. The extent of diabetic tissue damage is also determined by individual genetic determinants for susceptibility to diabetes and, similar to atherosclerosis, the presence of independent accelerating factors such as hypertension and dyslipidemia. ${ }^{8}$ The chronic nature of tissue damage leads to the inability of many people to recognize the presence of DM. This has triggered the American Diabetes Association (ADA) to issue a recommendation that all patients above 45 years old with risk factors should be checked for their blood glucose level. In anamnesis, in addition to age, information on the onset of DM is also crucial. However, accurate information on the onset is difficult to get due to the patient's ignorance of DM symptoms. Patients are usually unable to recall their past DM-related symptoms, such as polyuria, polydipsia, and polyphagia. Hence, T2DM screening and risk factor assessment using a validated tool should be considered for asymptomatic adults of any age who are overweight or obese (BMI $<25 \mathrm{~kg} / \mathrm{m}^{2}$ or $<23 \mathrm{~kg}$ / $\mathrm{m}^{2}$ in Asian Americans) and who have one or more additional risk factors for diabetes. ${ }^{9}$

Although this study could not reveal a significant correlation, previous studies have generally favored older age as a risk factor for DKD progression independent of the diabetes duration. An independent association between older age (62 years or above) and increased risk for DKD progression have been reported by Elley et al. ${ }^{10}$ The age median of patients in this study was lower than those in Elley's study (55.52 \pm 11.5 years). Besides the correlation with age, a significant correlation was also observed between the onset of DM (DM duration) and DKD $(\mathrm{p}=0.02)$. Wang et al. ${ }^{11}$ who studied DN in 220 patients underwent a renal biopsy to support DN diagnosis showed that the significant risk factors for DN are age, duration of diabetes, presence of retinopathy, 24-hour proteinuria, serum albumin, and SBP.

In this study, the DM control parameters used were the parameters according to the PERKENI guideline. Results show that the glycemic control achievement based on the HbA1c parameter was below the recommended level. Unsuccessful glycemic control achievement has become a global problem, which is not only seen in Low Middle-Income countries but also in the HighIncome countries. A study that involved 9.901 T2DM patients in Eastern Europe, Asia, and Latin America have shown that $36 \%$ of patients never had their HbA1c level measured. ${ }^{12}$ Compelling evidence shows that a long-term glycemic control, as expressed by the hemoglobin $(\mathrm{Hb})$ A1c level, is the main risk factor for microvascular complications in type 1 and type $2 \mathrm{DM}^{.{ }^{13}}$ No significant correlation was observed between uncontrolled HbA1c and stage of CKD in this study. Many patients with uncontrolled HbA1c fell into the mild CKD category (26/48\%), which may be linked to the cross-sectional study design. Poor HbA1c achievement in this study needs further investigation or prospective study about its risk factors and implication to the patients.

Although $\mathrm{HbA1c}$ is determined as a predictor of DM complication risks, the diagnostic cost is still expensive and are not widely affordable in Riau Province. The measurement of Fasting and Prandial plasma glucose with glucose sticks is more accessible for the patients. This study supported the emphasis on the importance of independent self-monitoring blood glucose (SMBG) by patients or caregivers. Long term benefits of SMBG could be more meaningful from the perspective of the HbA1c unavailability, especially in remote areas.

The attainment of the blood pressure, LDL cholesterol, and triglyceride goals according to PERKENI recommendations should be $74 \%$, $22 \%$, and $70 \%$ respectively. It is not easy to achieve these goals. Even the NHES study that involved more than 1000 participants, only discovered LDL below $100 \mathrm{mg} / \mathrm{dL}$ in $56.2 \%$ of the participants. A lower LDL achievement of $51.4 \%$ was even observed in a multi-center study in Africa. ${ }^{12,13}$ Although systolic hypertension does not correlate to renal insufficiency (CKD stage 3 and 4), 18.5\% of patients with systolic hypertension had declined GFR despite the lack of uremic syndrome. Chan et al. ${ }^{12}$ reported that 
only $20-40 \%$ of T2DM patients (9.901) were on target for $\mathrm{A} 1 \mathrm{C}$, blood pressure, or lipids. The measurements necessary to observe the link between hypertension, lipid disorders, and DM are still problems in Riau Province, Indonesia. Primary health care facilities and peripheral hospitals in this province do not have adequate laboratory capacity. The available rapid test kits do not support LDL, HDL, and TG measurements. This leads to ignorance towards these conditions in patients and deprives patients of receiving appropriate treatments for lipid disorders. Only simvastatin is available in primary health care facilities.

The examinations above are actually simple physical examinations that should not be missed in the management of DM patients. Unfortunately, this is not the case, which is reflected in the poor outcome. Patients are not aware of the extent of the manifestation of obesity. The anthropometric index is sensitive for predicting poor glycemic. Arfianti et al. ${ }^{14}$ stated that WHR and WHtR are anthropometric indexes that correlate to glycemic control although WHR and WHtR alone are not accurate predictors for DM.The health provider should educate DM patients on the importance of modifying lifestyle to reduce BMI and glycemic control. A simple diet recommendation such as plate model and $3 \mathrm{~J} \mathrm{jadwal/jam} \mathrm{makan/mealtime,} \mathrm{jumlah}$ makanan/amount of food, and jenis makanan/ type of food) can be given to patients and can be easily understood even by patients with low education background.

The End Stage Renal Disease is the last stage of CKD that raises concerns, both for doctors and patients. DN is characterized by structural and functional changes including mesangial expansion, thickeningofthe basementmembrane, and, characteristic nodular glomerulosclerosis in the glomerulus (Kimmelstiel-Wilson nodules). In early DN, tubular hypertrophy is present; however, interstitial fibrosis with tubular atrophy eventually develops along with arteriolar hyalinosis. In advanced cases, infiltrations of macrophages and T-lymphocytes are observed. Ultrastructurally, podocyte loss and reduced endothelial cell fenestration were seen. These characteristic pathological changes are shown in the Figure. Functionally, early glomerular hyperfiltration and increased albumin excretion with advancing nephropathy as well as increasing proteinuria and declining GFR are apparent. A brief description of the functional and cellular pathology is provided below. Although it is conceptually easier to describe these pathways individually, these pathways overlap and interact with one another in vivo and mutually enhance their biophysiological effects. ${ }^{15}$

The prevalence of DKD in the US population (NHANES) is increasing by years started from $2.2 \%$ in $1994-2004$ to $3.7 \%$ in $2005-2008 .{ }^{4}$ Proteinuria can be used to monitor the progress of kidney disease and to assess the therapeutic response. Protein measurement panels can also help differentiate pre-renal and postrenal diseases. Other biochemical and renal markers are creatinine serum, ureum, uric acid, cystatin $C, \beta 2$ microglobulin, inulin, and radioisotope. ${ }^{17}$ Diabetes mellitus patients with kidney complications have a high prevalence of proteinuria. The data showed a high prevalence of proteinuria of more than $40 \%$. Sugaswara in Tsukuba suggested that microalbuminuria occurred in 193 of 812 patients $(23,7 \%)$ during the observation period of $($ mean \pm SD) $4.3 \pm 2.7$ years and that even after adjustment for mean $\mathrm{HbA1c}$, the HbA1c variability is still a significant predictor of microalbuminuria, regardless the mean HbA1c. ${ }^{17}$

Kim et al. $^{18}$ analyzed the role of albuminuria and non-albumin (NAPCR) urine using ELISA and revealed that the average rate of eGFR decline over a median of 4.2 years of follow-up is -2.48 $\mathrm{mL} / \mathrm{min} / 1.73 \mathrm{~m}^{2} /$ year. After adjustment for nine clinical parameters affecting the eGFR decline, only NAPCR remains significantly associated with GFR decline.

In DM patients suspected to have diabetic nephropathy, microalbuminuria examination is an important marker in a very early stage. In the early stages, renal hypertrophy occurs, and the hyperfunction and thickening of the glomerular membrane and tubules are observed. At this stage, there are no clinical symptoms that lead to impaired kidney functions but the process of glomerulosclerosis continues to occur for the next 7-10 years and ends with increased glomerular permeability. This increased permeability causes albumin to escape glomerular filtration and to be detected in urine. If this can be detected early and adequate treatment is provided to control blood glucose and monitor blood pressure properly, kidney failure can be prevented. ${ }^{19}$

The significant correlation between protein urine and declined GFR in this study is not supported by another study conducted at RSUP Dr. M. Djamil, Padang, in 2017. This difference may be linked with the sample. The study in Padang involved all CKD patients while this study only analyzed DM patients. Guh's research in 2010 in Taiwan concluded that urine protein can 
be used as a biomarker of chronic kidney disease using the quantitative method, not the semiquantitative method. According to Guh, urine protein examination method using dipstick has a lower sensitivity and specificity when compared to ACR examination (Albumin to Creatinine Ratio). ${ }^{20}$

Although the achievement of DM control was below the indicator, a high percentage of Nephropathy - proteinuria of $40.7 \%$ was revealed with $40.9 \%$ of them were found to be CKD stages 3 and 4 . The correlation between proteinuria and declined GFR was statistically significant ( $p=0.016)$. The onset of DM has a trend to be used as a predictor $(p=0.02)$. No correlation between HbA1c level and declined GFR may be influenced by the cross-sectional study design. It will be nteresting to perform a prospective study on proteinuria modification as a strong predictor in early detection of diabetic nephropathy as an alternative to renal biopsy or albumin urine creatinine ratio, which are not widely affordable for health care facilities in remote areas.

\section{Acknowledgment}

We thank Ridhola Fitbriansyah for his assistance in patient diagnosis in T2DM complication research. We also thank Rahmi Putri Ferdiyani for her administrative assistance. This study is a part of research funded by the Faculty of Medicine Universitas Riau on Screening of T2DM macro and microvascular complications in Pekanbaru (Contract No. B/34/UN19.5.1.1.8/ PT.01.05/UPPM/2019) and IL-10 gene promoter polymorphism (No: B/59/UN19.5.1.1.8/ PT.01.05/UPPM/2019).

\section{References}

1. Soelistijo SA, Novida H, Suastika K SP. Pengelolaandanpencegahandiabetesmelitus tipe 2 di indonesia 2015. 2015.-KonsensusPengelolaan-dan-Pencegahan-Diabetesmelitus-tipe-2-di-Indonesia-PERKENI-2015. Available from: https://pbperkeni.or.id/wpcontent/uploads/2019/01/4

2. Evans JL, Goldfine ID. A new road for treating the vascular complications of diabetes: so let's step on the gas. Diabetes. 2016;65(2):346-8.

3. Chawla A, Chawla R, Jaggi S. Microvasular and macrovascular complications in diabetes mellitus: Distinct or continuum?. Indian J
Endocrinol Metab. 2016;20(4):546-53.

4. Dias JP, Shardell M, Golden SH, Ahima RS, Crews DC. Racial/ethnic trends in prevalence of diabetic kidney disease in the United States. Kidney Int Rep. 2018;4(2):334-7.

5. Vistisen D, Andersen GS, Hulman A, Persson F, Rossing P, Jørgensen ME. Progressive Decline in Estimated Glomerular Filtration rate in patients with diabetes after moderate loss in kidney function-even without albuminuria. Diabetes Care. 2019;42(10):1886-94.

6. Wanner C, Ketteler M. Chronisches Nierenversagen [chronic kidney disease]. Dtsch Med Wochenschr. 2017;142(3):193196.

7. Yang Z, Feng L, Huang Y, Xia N. A differential diagnosis model for diabetic nephropathy and non-diabetic renal disease in patients with type 2 diabetes complicated with chronic kidney disease. Diabetes Metab Syndr Obes. 2019;12:1963-72.

8. Giacco F, Brownlee M. Oxidative stress and diabetic complications. Circ Res. 2010;107(9):1058-70.

9. American Diabetes Association. Classification and diagnosis of diabetes: standards of medical care in diabetes-2018. Diabetes Care. 41(Supplement 1): S13-27.

10. Elley CR, Robinson T, Moyes SA, Kenealy T, Collins J, Robinson E, et al. Derivation and validation of a renal risk score for people with type 2 diabetes. Diabetes Care. 2013;36(10):3113-20.

11. Wang X, Li J, Huo L, Feng Y, Ren L, Yao X, et al. Clinical characteristics of diabetic nephropathy in patients with type 2 diabetic mellitus manifesting heavy proteinuria: A retrospective analysis of 220 cases. Diabetes Res Clin Pract. 2019;157:107874.

12. Chan JCN, Gagliardino JJ, Baik SH, Chantelot JM, Ferreira SRG, Hancu N, et al. Multifaceted determinants for achieving glycemic control the international diabetes management practice study (IDMPS). Diabetes Care. 2009;32(2):227-33.

13. Guiseppe P, Solini A, Bonora E, Fondelli C, Orsi E, Zerbini G, et al. HbA1c variability as an independent correlate of nephropathy, but not retinopathy, in patients with type 2 diabetes: the Renal Insufficiency And Cardiovascular Events (RIACE) Italian multicenter study. Diabetes Care. 2013;36(8):2301-10.

14. Arfianti A, Deyana F, Rosdiana D, Ardin NY, Armi W, Kesumah DIS. Akurasi indeks antropometri obesitas dalam mempediksi 
kontrol glicemic pasien diabetes mellitus tipe 2 di puskesmas kota Pekanbaru. MKB. 2018;50(3):140-6.

15. Lim AKH. Diabetic nephropathycomplications and treatment. Int J Nephrol Renovasc Dis. 2014;7:361-81.

16. Verdiansah. Pemeriksaan fungsi ginjal. CDK. 2016;43(2):148-54.

17. Sugawara A, Kawai K, Motohashi S, Saito K, Kodama S, Yachi Y, et al. HbA(1c) variability and the development of microalbuminuria in type 2 diabetes : Tsukuba Kawai Diabetes Registry 2. Diabetologia. 2012;55(8):212831.

18. Kim JH, Kim SS, Kim IJ, Lee MJ, Jeon YK, Kim
$\mathrm{BH}$, et al. Nonalbumin proteinuria is a simple and practical predictor of the progression of early-stage type 2 diabetic nephropathy. J Diabetes Complications. 2017;31(2):39599.

19. Powers AC. Diabetes mellitus: diagnosis, classification, and pathophysiology. In: Harrison's Principles of Internal Medicine. $19^{\text {th }}$ ed. 2015. p. 2399-407.

20. Surya AM, Pertiwi D, Masrul M. Hubungan protein urine dengan laju filtrasi glomerulus pada penderita penyakit ginjal kronik dewasa di RSUP Dr. M. Djamil Padang tahun 2015-2017. J Kesehatan Andalas. 2018;7(4):469-74. 